\title{
PENGARUH REAL EARNING MANAGEMENT TERHADAP ARUS KAS OPERASI PERUSAHAAN DENGAN KUALITAS AUDIT SEBAGAI VARIABEL MODERASI (Studi pada Perusahaan Manufaktur yang Terdaftar di BEI)
}

\author{
Felicianus Adi Nugroho \\ Dewi Ratnaningsih
}

Program Studi Akuntansi, Fakultas Ekonomi, Universitas Atma Jaya Yogyakarta Jalan Babarsari 43 - 44, Yogyakarta

\begin{abstract}
Abstrak
Penelitian ini bertujuan untuk mengetahui pengaruh real earning management yang merupakan proksi dari manajemen laba terhadap kemampuan prediktif dari laporan keuangan melalui arus kas operasi perusahaan. Peneliti juga mempertimbangkan adanya pengaruh yang diberikan oleh kualitas audit terhadap hubungan antara real earning management dengan arus kas operasi perusahaan.

Sampel dalam penelitian adalah perusahaan manufaktur yang terdaftar di Bursa Efek Indonesia selama periode 2010-2012. Berdasarkan kriteria pengamatan yang telah ditetapkan sebelumnya terdapat 249 data perusahaan yang digunakan dalam penelitian ini.

Hasil dari penelitian ini mengungkapkan bahwa real earning management memiliki pengaruh terhadap kemampuan prediktif laporan keuangan melalui arus kas operasi. Kualitas audit juga dapat mempengaruhi tindakan manajemen laba yang dilakukan oleh perusahaan dan berakibat juga terhadap arus kas operasi perusahaan. Jadi secara keseluruhan kualitas audit dapat mempengaruhi tindakan manajemen laba dan dapat dipastikan juga kemampuan prediktif laporan keuangan perusahaan.
\end{abstract}

Kata Kunci : real earning management, arus kas operasi, dan kualitas audit.

\section{Pendahuluan}

A. Latar Belakang

Pasar modal yang berkembang saat ini dapat dijadikan lahan bisnis dan memberikan peluang keuntungan yang sangat besar bagi para investor. Untuk itu dapat dipastikan bahwa investor akan mempertimbangkan secara detail mengenai kemungkinan hasil yang akan diterima dengan mencari informasi sebanyak-banyaknya mengenai kondisi keuangan perusahaan ataupun kinerja perusahaan. Oleh karena itu dalam kerangka dasar penyusunan laporan keuangan dijelaskan karakteristik kualitatif informasi laporan yaitu keandalan, relevansi, dapat dipahami dan dapat dibandingkan

Salah satu informasi keuangan yang paling banyak digunakan sebagai dasar pengambilan keputusan adalah laba, dan investor terkadang hanya mendasarkan keputusan investasi pada besarnya jumlah laba dan tidak memperhatikan bagaimana laba tersebut dihasilkan. Kondisi tersebut mengakibatkan manajer sering berusaha menonjolkan prestasinya melalui tingkat keuntungan laba yang dicapai. Cara yang dapat dilakukan oleh manajemen dalam memenuhi target yang diberikan oleh para pemegang saham/pemilik adalah manajemen laba (earnings management). 
Manajemen laba yang dilakukan oleh manajer tersebut timbul karena adanya masalah keagenan yaitu konflik kepentingan antara pemilik/pemegang saham (principal) dengan pengelola/manajemen (agent). Hal ini diakibatkan tidak bertemunya utilitas maksimal di antara mereka karena manajemen memiliki informasi tentang perusahaan lebih banyak daripada pemegang saham sehingga terjadi asimetri informasi dan memungkinkan manajemen melakukan praktik akuntansi yang mementingkan pribadi dengan orientasi pada laba untuk mencapai suatu kinerja tertentu.

Graham et al. (2005) memberikan bukti empiris bahwa para manajer cenderung melakukan aktivitas manajemen laba riil dibandingkan dengan manajemen laba akrual. Hal ini disebabkan karena aktivitas manajemen laba riil sulit dibedakan dengan keputusan bisnis optimal dan lebih sulit dideteksi. Menurut Roychowdhury (2006), meskipun terdapat biaya yang terkait dengan manipulasi aktivitas nyata, manajemen tidak hanya mengandalkan tindakan manipulasi melalui akrual dalam memanipulasi laba karena manipulasi aktivitas riil dapat digunakan apabila manipulasi akrual tidak mencapai target. Selain itu, manipulasi akrual hanya dapat dilakukan pada akhir periode untuk mencapai target, lain halnya dengan manipulasi melalui aktivitas riil yang dapat dilakukan sepanjang tahun dan sulit dideteksi. Oleh karena itu, metode manipulasi aktivitas riil menjadi pilihan utama untuk saat ini bagi manajer yang dapat dilakukan untuk mengatur laba dibandingkan dengan manajemen laba akrual yang mudah dideteksi.

Manajemen laba riil yang dilakukan oleh pihak manajemen akan memberikan dampak secara langsung terhadap kemampuan prediktif informasi laporan keuangan atas future profitability perusahaan. Dampak yang timbul ini dapat bersifat mengurangi kemampuan prediktif dari laporan keuangan atau oportunistik dimana pihak manajemen melaporkan laba perusahaan sesuai dengan keinginan mereka untuk memaksimumkan keuntungan pribadi dan mengakibatkan keputusan yang diambil akan merugikan investor. Selain itu dampak yang muncul dapat juga tidak mengurangi kemampuan prediktif dari laporan keuangan atau efisien dimana pihak manajemen lebih memperhatikan tingkat keandalan laba yang disajikan dan mengakibatkan keputusan yang diambil menguntungkan pihak investor dan manajemen.

Future profitability adalah salah satu pengukuran yang dapat dijadikan pedoman bagi para investor untuk dapat mengetahui potensi masa depan yang dimiliki oleh sebuah perusahaan untuk menghasilkan suatu keuntungan/ laba dari kegiatan pengelolaan kekayaan. Pengukuran terhadap future profitability menurut penelitian dari Subramanyam dapat dilakukan dengan mengukur arus kas operasi masa depan, menghitung selisih laba yang diperoleh dari tahun ke tahun ataupun dengan mengukur besaran dividen yang dibagikan pada periode tersebut.

Dampak yang ditimbulkan dengan adanya manajemen laba riil terhadap kemampuan prediktif laporan keuangan akan menimbulkan adanya salah persepsi dan mengurangi relevansi dari laporan keuangan. Oleh karena itu dibutuhkan pihak lain yang dapat memberikan pernyataan keandalan penyajian laba dalam laporan keuangan yang telah dibuat manajer sebagai penyelesaian masalah keagenan yang dimiliki pihak agen dan prinsipal, yaitu akuntan publik. Akuntan publik sebagai pihak yang dipercaya untuk memberikan penilaian terhadap suatu laporan keuangan dibutuhkan oleh pihakpihak yang membutuhkan informasi dalam laporan keuangan tersebut. Melalui pengauditan, pihak-pihak yang berkepentingan dengan perusahaan dapat memverifikasi keandalan laporan keuangan (Zhou dan Elder, (2001) dalam Wirjono (2005)). 
Jasa audit yang berkualitas akan berdampak pada peningkatan kepercayaan pengguna laporan keuangan bahwa laporan keuangan merupakan laporan keuangan yang berkualitas, sehingga dapat digunakan sebagai dasar pengambilan keputusan investasi. Kualitas audit diduga dapat mempengaruhi hubungan manajemen laba dengan keandalan informasi keuangan perusahaan yang disajikan melalui laporan keuangan. Jasa audit yang berkualitas dapat mempengaruhi kecenderungan manajemen dalam melakukan manajemen laba. Hal ini dikarenakan semakin berkualitas audit maka semakin dapat mengurangi kecenderungan tergerusnya kemampuan prediktif yang dimiliki oleh laporan keuangan dikarenakan adanya manajemen laba.

\section{B. Rumusan Masalah}

Berdasarkan latar belakang masalah dan beberapa pemaparan hasil penelitian sebelumnya, maka masalah dalam penelitian dapat dirumuskan sebagai berikut, yaitu: "Apakah Real Earning Management mempengaruhi arus kas operasi perusahaan manufaktur yang terdaftar pada Bursa Efek Indonesia (BEI) periode 2010-2012 dengan dimoderasi oleh kualitas audit?"

\section{Tujuan Penelitian}

Penelitian ini ingin menguji secara empiris tentang pengaruh Real Earning Management terhadap arus kas operasi perusahaan manufaktur dengan dimoderasi oleh kualitas audit. Hasil pengujian ini diharapkan mampu melihat bahwa Real Earning Management akan mempengaruhi arus kas operasi perusahaan dan kualitas audit dapat memoderasi pengaruh Real Earning Management terhadap arus kas operasi perusahaan.

\section{Landasan Teori dan Pembentukan Hipotesis}

A. Manajemen Laba

Penelitian ini menggunakan teori manajemen laba. Scott (2003) mengungkapkan bahwa manajemen laba adalah keputusan manajer dalam memilih kebijakan akuntansi yang mempengaruhi laba untuk mencapai tujuan tertentu. Pemilihan kebijakan akuntansi didasari atas tujuan mendapatkan manfaat privat manajer atau meningkatkan nilai perusahaan.

\section{B. Pengaruh Manajemen Laba Terhadap Kualitas Informasi Laporan}

\section{Keuangan}

Informasi yang diberikan perusahaan berupa laporan keuangan kerap dijadikan acuan bagi penggunanya. Dengan kata lain, kualitas informasi laporan keuangan merupakan sarana penting bagi para pemegang saham atau pihak yang memiliki kepentingan lain untuk mendapat informasi sebanyak-banyaknya.Oleh karena itu, informasi yang terkandung di dalam laporan keuangan harus berkualitas dan sesuai dengan aturan yang berlaku sehingga dapat berdampak positif bagi penggunanya.

\section{Manajemen Laba Riil (Real Earning Management)}

Schiper (1989) dalam Ferdawati (2008) mendefinisikan manajemen laba sebagai suatu intervensi yang sengaja dilakukan untuk memperoleh beberapa keuntungan pribadi pihak tertentu. Ada beberapa cara yang dilakukan manajemen dalam melakukan manajemen laba, antara lain melalui manajemen laba akrual dan manajemen laba riil. Manajemen laba riil merupakan manipulasi yang dilakukan oleh manajemen melalui aktivitas perusahaan sehari-hari selama periode akuntansi. Motivasi utama atas manipulasi aktivitas riil adalah waktu (timing) manajemen laba. Manajemen laba riil dapat dilakukan kapan saja sepanjang periode akuntansi dengan tujuan spesifik, yaitu 
memenuhi target laba tertentu, menghindari kerugian, dan mencapai target ramalan analis. Selain itu, manajemen laba riil sulit untuk dideteksi oleh auditor..

\section{Kualitas Audit}

Kualitas audit didefinisikan sebagai kemungkinan (joint probability) dimana seorang auditor akan menemukan dan melaporkan pelanggaran yang ada dalam sistem pelaporan keuangan kliennya. Kemungkinan dimana auditor akan menemukan salah saji tergantung pada kualitas pemahaman auditor (kompetensi) sementara tindakan melaporkan salah saji tergantung pada independensi auditor (De Angelo (1981) dalam Elfarini (2007)). Kualitas audit ditentukan oleh dua hal yaitu kompetensi dan independensi.

\section{E. Hipotesis}

1. Pengaruh Real Earning Management Terhadap Arus Kas Operasi Satu Tahun Kedepan

Penelitian yang dilakukan oleh Subramanyam (1996) dilakukan terhadap 21.135 laporan keuangan dari 2.808 perusahaan yang terdaftar di Center for Research in Security Prices dan Compustat database sepanjang tahun 19731993. Dari data tersebut diuji apakah manajemen laba melalui discretionary accruals dapat digunakan untuk memprediksi arus kas operasi masa depan, laba dan dividen yang nantinya dapat digunakan oleh pihak investor untuk mengambil kebijakan yang berasal dari informasi laba pada periode berjalan maupun kinerja dimasa yang akan datang. Hasil penelitiannya menunjukkan bahwa manajemen laba memiliki pengaruh positif terhadap nilai arus kas operasi satu tahun kedepan dimana informasi yang dihasilkan akan meningkatkan kemampuan prediktif laporan keuangan.

Penelitian dari Rezaei, 2012 ingin membuktikan tipe manajemen laba yang dilakukan di negara Iran yaitu manajemen laba efisien atau oportunistik. Penelitiannya menggunakan sampel sebanyak 167 perusahaan selama periode 2004-2009. Untuk mengetahui tipe manajemen laba, penelitiannya menguji pengaruh antara manajemen laba dengan future profitability. Tiga proksi digunakan untuk menghitung rasio future profitability yaitu : (1) Arus kas dari aktivitas operasi satu tahun ke depan, (2) non-discretionary net income satu tahun ke depan, (3) perubahan laba. Penelitiannya juga mengungkapkan jika pengaruh Earning Management terhadap future profitability positif, maka jenis manajemen laba akan efisien dimana pihak investor/pemegang saham dan manajemen akan sama-sama diuntungkan. Namun, jika pengaruh Earning Management terhadap future profitability negatif, maka jenis manajemen laba akan oportunistik dimana pihak manajemen akan lebih diuntungkan dengan adanya manajemen laba.

H1 : Real Earning Management berpengaruh terhadap arus kas operasi perusahaan satu tahun kedepan.

2. Kualitas Audit Mempengaruhi Interaksi Real Earning Management dengan Arus Kas Operasi Perusahaan

Manajemen laba riil yang dilakukan manajer tidak menunjukkan informasi yang sebenarnya tentang laba dan kinerja perusahaan sehingga dapat menyesatkan pihak pengguna laporan. Oleh karena itu, diperlukan suatu mekanisme untuk membatasi perilaku oportunis manajemen ini agar laba yang disajikan menggambarkan keadaan yang sebenarnya. Salah satu mekanisme yang diharapkan dapat mengontrol perilaku oportunis manajemen adalah dengan 
menerapkan kualitas audit yang baik. Audit yang berkualitas akan berdampak pada peningkatan kepercayaan pengguna laporan keuangan bahwa laporan keuangan merupakan laporan keuangan yang berkualitas, sehingga dapat digunakan sebagai dasar pengambilan keputusan ekonomi. Becker et al. (1998) menyatakan bahwa kualitas audit berpengaruh negatif terhadap intensitas manajemen laba, semakin tinggi kualitas audit, maka manajemen laba semakin turun.

Jasa audit yang berkualitas akan berdampak pada peningkatan kepercayaan pengguna laporan keuangan bahwa laporan keuangan merupakan laporan keuangan yang berkualitas, sehingga dapat digunakan sebagai dasar pengambilan keputusan investasi. Jasa audit yang berkualitas dapat mempengaruhi kecenderungan pihak manajemen perusahaan untuk melakukan manajemen laba. Hal ini dikarenakan semakin berkualitas audit maka semakin dapat mengurangi manajemen laba sehingga semakin berkurang pula kecenderungan pihak manajemen untuk melakukan manajemen laba dan pada akhirnya meningkatkan keandalan informasi keuangan yang disajikan perusahaan.

Kualitas audit yang tinggi dapat dilihat dari verifikasi keandalan laporan keuangan yang dimiliki oleh perusahaan melalui opini audit yang dikeluarkan oleh KAP. Besarnya KAP akan sangat mempengaruhi independensi dan kemampuan mendeteksi manajemen laba yang dilakukan oleh perusahaan, sehingga KAP big four dapat dikatakan lebih mampu untuk mendeteksi manajemen laba dibandingkan dengan KAP non big four. Oleh sebab itu tingkat manajemen laba yang dilakukan oleh perusahaan yang menggunakan KAP big four akan menurun.

Studi Ardiati (2003) dan Atiqah (2012), menggunakan kualitas audit sebagai variabel pemoderasi. Dalam Ardiati (2003) kualitas audit merupakan variabel pemoderasi antara pengaruh manajemen laba terhadap return saham. Hasilnya menunjukkan bahwa earnings management yang positif dapat diperlemah dengan adanya Audit oleh KAP Big 4 dan kualitas audit merupakan variabel pemoderasi antara earnings management dan return saham. Atiqah (2012) dalam penelitiannya menggunakan data sekunder yang berasal dari laporan keuangan perusahaan-perusahaan manufaktur yang terdaftar di Bursa Efek Indonesia pada tahun 2008-2010. Hasil penelitian ini menunjukkan bahwa kualitas audit dapat memoderasi risiko litigasi terhadap manajemen laba. Selanjutnya Chen et al. (2011) menguji pengaruh kualitas audit terhadap manajemen laba dan cost of equity capital dan hasilnya menunjukkan kualitas audit dapat mempengaruhi hubungan antara manajemen laba dan cost of equity capital.

H2 : Kualitas audit berpengaruh terhadap interaksi manajemen laba riil dengan arus kas operasi perusahaan satu tahun kedepan.

\section{Metode Penelitian}

\section{A. Populasi dan Sampel Penelitian}

Dalam penelitian ini populasinya adalah perusahaan manufaktur yang terdaftar di BEI selama tahun 2010-2012. Pemilihan perusahaan manufaktur dipilih karena perusahaan manufaktur kebanyakan melakukan praktek earning management dibandingkan dengan perusahaan lainnya serta minimnya aturan atau regulasi dari 
pemerintah atas kebijakan-kebijakan ekonomi pada perusahaan manufaktur sehingga memunculkan peluang manajer untuk membuat kebijakan-kebijakan terkait estimasi akuntansi (Sanjaya, 2010).

\section{B. Metode Proses Pengambilan Sampel}

Pemilihan sampel dilakukan secara purposive sampling. Metode ini dilakukan dengan mengambil sampel dari populasi berdasarkan suatu kriteria tertentu. Kriteria tersebut yaitu :

1) Perusahaan yang laporan keuangannya dinyatakan dalam mata uang Rupiah secara berturut-turut selama tahun pengamatan yaitu tahun 2010 sampai 2012.

2) Perusahaan yang mencukupi tersedianya informasi dan lengkap berhubungan dengan penelitian.

Pengambilan sampel dalam penelitian ini dilakukan dengan menjumlahkan perusahaan yang memenuhi kriteria penelitian selama periode pengamatan yaitu dari tahun 2010-2012 yang disebut sebagai metoda penggabungan data (pooled data).

\section{Variabel Dependen}

Data terkait arus kas operasi diperoleh dari laporan keuangan perusahaan yang sesuai dengan tahun pengujian akan dilakukan. Dalam penelitian ini variabel dependen menggunakan proksi arus kas dari aktivitas operasi satu tahun ke depan karena memiliki pengaruh paling siginfikan dan besar daripada alat ukur yang lain sesuai dengan penelitian Rezaei (2012) yaitu:

$$
\frac{\mathrm{CFO}}{\mathrm{TA}+1}^{\mathrm{TA}}
$$

Keterangan :

$\mathrm{CFO}_{\mathrm{t}+1}$ : $\quad$ Arus kas operasi satu tahun ke depan perusahaan i

TA : $\quad$ Total aset perusahaan $\mathrm{i}$ pada periode $\mathrm{t}$

\section{Variabel Independen \\ Real Earning Management}

Real Earning Management merupakan manajemen laba yang dilakukan oleh pihak manajemen dengan cara melakukan manipulasi kebijakan aktivitas perusahaan sehari-hari selama periode akuntansi. Manajemen laba riil dalam penelitian ini mengikuti Roychowdhury (2006) dengan 3 proksi yang dapat menentukan real earnings management yang dilakukan oleh perusahaan yaitu abnormal cash flow operation, abnormal production cost dan abnormal discretionary expenditure. Penelitian ini menggunakan proksi real earnings management (REM) dengan menentukan aliran kas operasional abnormal (Abnormal CFO). Proksi ini digunakan karena mempunyai adjusted $R 2$ yang cukup tinggi dan korelasi yang sesuai prediksi paling tinggi dibandingkan model yang lain. Pengukuran real earning management yang dilakukan oleh perusahaan akan berbanding terbalik dengan besarnya abnormal CFO yang dimiliki oleh perusahaan. Hal ini dikarenakan semakin kecil arus kas operasi abnormal perusahaan maka akan semakin besar kemungkinan perusahaan untuk melakukan real earning management (Roychowdury, 2006). Pengukurannya dihitung melalui selisih antara aliran kas operasi aktual dengan aliran kas operasi normal.

$$
\mathrm{CFO}_{t} / A_{t-1}=\alpha_{0}+\alpha_{1}\left(1 / A_{t-1}\right)+\beta_{1}\left(S_{t} / A_{t-1}\right)+\beta_{2}\left(\Delta S_{t} / A_{t-1}\right)+\varepsilon_{t},
$$




\section{E. Variabel Moderasi \\ Kualitas Audit}

Kualitas audit merupakan kemungkinan (joint probability) dimana seorang auditor akan menemukan dan melaporkan pelanggaran yang ada dalam sistem pelaporan keuangan kliennya. Jasa audit berkualitas akan berdampak pada peningkatan kepercayaan pengguna laporan keuangan. Kualitas audit yang tinggi dapat dilihat dari ukuran besarnya KAP. KAP yang lebih besar lebih memiliki sumber daya yang besar untuk meningkatkan kualitas audit. KAP yang besar juga dianggap lebih memiliki keahlian dan insentif sehingga dapat mempengaruhi ddan membatasi tindakan manajemen laba yang dilakukan oleh manajemen. Dalam penelitian ini yang menjadi variabel moderasi adalah kualitas audit yang dapat diproksikan dan diberi skor 1 untuk perusahaan yang diaudit oleh KAP Big Four dan 0 adalah untuk perusahaan yang tidak diaudit oleh KAP Big Four.

\section{F. Model Empiris}

Pengujian hipotesis dilakukan dengan regresi linier berganda pada program SPSS sesuai dengan model empiris yang dibangun. Model dalam penelitian ini adalah sebagai berikut :

Model penelitian yang digunakan dalam pengujian hipotesis :

$$
\mathbf{y}=\mathbf{a}+\mathbf{b}_{1} x_{1}+\mathbf{b}_{2} \mathbf{z}+\mathbf{b}_{3} x_{1} \mathbf{z}+\mathbf{e}
$$

Dimana :

$b_{1}, b_{2}, b_{3}=$ koefisien variabel

a $\quad=$ konstanta

$\mathrm{y}=$ arus kas operasi satu tahun ke depan

$\mathrm{x}_{1} \quad=$ real earning management

$\mathrm{Z} \quad=$ kualitas audit

e $\quad=$ error

\section{G. Kriteria Penerimaan Hipotesis}

Terdapat dua hipotesis dalam penelitian ini yaitu :

H1 : Real Earning Management berpengaruh terhadap arus kas operasi perusahaan satu tahun kedepan.

H1 diterima apabila p value koefisien < 0,05 artinya Real Earning Management akan berpengaruh terhadap CFOt +1 .

H2 : Kualitas audit berpengaruh terhadap hubungan Real Earning Management dengan arus kas operasi perusahaan satu tahun kedepan.

$\mathrm{H} 2$ diterima apabila $\mathrm{p}$ value koefisien $<0,05$ artinya kualitas audit berpengaruh terhadap hubungan Real Earning Management dengan CFOt+1.

\section{Analisis Data dan Pembahasan}

\section{A. Uji Normalitas}

Uji normalitas data dilakukan sebelum data diolah berdasarkan model-model penelitian yang diajukan. Uji normalitas dalam penelitian ini menggunakan uji Kolmogorov-Smirnov yang bertujuan untuk mendeteksi setiap residual terdistribusi normal atau tidak. Data dinyatakan normal jika nilai signifikansi lebih dari 0,05 dan hasil dari pengujian ini menyatakan bahwa nilai signifikansinya melebihi 0,05 ( $>5 \%)$ 
yaitu sebesar 0,294, maka dapat dinyatakan bahwa data yang digunakan dalam penelitian ini terdistribusi secara normal

\section{B. Uji Asumsi Klasik}

Hasil dari pengujian asumsi klasik tidak terdapat heteroskedastisitas, multikolinearitas, dan autokorelasi pada setiap model penelitian.

\section{Pembahasan}

\begin{tabular}{|c|c|c|c|c|c|}
\hline \multirow{2}{*}{ Model } & \multicolumn{2}{|c|}{$\begin{array}{c}\text { Unstandarized } \\
\text { Coefficients }\end{array}$} & $\begin{array}{c}\text { Standarized } \\
\text { Coefficients }\end{array}$ & \multirow{2}{*}{ t } & \multirow{2}{*}{ Sig. } \\
\cline { 2 - 6 } & B & Std. Error & B & & \\
\hline Constant & 0.049 & 0.010 & & 5.010 & 0.000 \\
\hline REM -> CFO t+1 & -0.204 & 0.073 & -0.215 & -2.813 & 0.005 \\
\hline KA -> (REM -> CFO t+1) & 0.201 & 0.100 & 0.153 & 1.997 & 0.047 \\
\hline Nilai F & 13.274 & & \\
Sig. & $0.000^{\mathrm{a}}$ & & \\
Adj. R-squared 0.129 & & & \\
R-square & 0.140 & & \\
\hline
\end{tabular}

Dari tabel di atas dapat diketahui bahwa manajemen laba riil yang diinteraksikan dengan arus kas operasi abnormal mempunyai koefisien $\rho$-value sebesar 0.005 dan nilai $\beta$ negatif. Hal ini menunjukkan bahwa koefisien $\rho$-value Real Earning Management < nilai alpha (5\%), dengan demikian hipotesis diterima, yang artinya terdapat pengaruh yang signifikan antara manajemen laba riil yang diinteraksikan dengan arus kas operasi abnormal terhadap arus kas operasi satu tahun ke depan (CFOt+1). Hasil pengujian juga menunjukkan bahwa manajemen laba riil yang diinteraksikan dengan arus kas operasi abnormal berpengaruh positif terhadap arus kas operasi satu tahun ke depan $(\mathrm{CFOt}+1)$ pada perusahaan manufaktur yang terdaftar dalam Bursa Efek Indonesia periode 20102012.

$\beta<0,00$ menunjukkan bahwa hubungan antara manajemen laba riil dengan arus kas operasi satu tahun ke depan berpengaruh positif. Pengaruh positif manajemen laba riil yang diinteraksikan dengan arus kas operasi abnormal terhadap arus kas operasi satu tahun ke depan $(\mathrm{CFOt}+1)$ diakibatkan oleh perusahaan yang melakukan manajemen laba riil akan cenderung memanipulasi aktivitas sepanjang tahun dan mengakibatkan arus kas operasi abnormal semakin kecil. Hal ini didukung oleh penelitian Roychowdury pada tahun 2006 yang menunjukkan bahwa dengan adanya manajemen laba riil yang dilakukan oleh perusahaan maka semakin kecil arus kas operasi abnormal yang dimiliki oleh perusahaan tersebut. Secara keseluruhan hasil yang didapat adalah semakin kecil arus kas operasi abnormal perusahaan maka semakin besar kemungkinan perusahaan melakukan manajemen laba riil dan akan berdampak pada meningkatnya arus kas operasi satu tahun ke depan. Oleh karena itu meskipun hasil yang didapat pada penghitungan regresi bernilai negatif namun pengaruh Real Earning Management terhadap arus kas operasi satu tahun ke depan tetap positif. 
Kualitas audit yang diinteraksikan dengan besarnya ukuran KAP yang ditunjuk oleh perusahaan untuk memberikan opininya mempunyai koefisien $\rho$-value sebesar 0.047. Hal ini menunjukkan bahwa koefisien $\rho$-value kualitas audit $<$ nilai alpha $(5 \%)$, dengan demikian hipotesis diterima, yang artinya terdapat pengaruh signifikan kualitas audit yang diinteraksikan dengan besarnya ukuran KAP yang ditunjuk oleh perusahaan untuk memberikan opininya terhadap hubungan antara manajemen laba riil yang diinteraksikan dengan arus kas operasi abnormal terhadap arus kas operasi satu tahun ke depan.

Hasil pengujian kualitas audit sebagai variabel pemoderasi hubungan antara manajemen laba riil yang diinteraksikan dengan arus kas operasi abnormal terhadap arus kas operasi satu tahun ke depan $(\mathrm{CFOt}+1)$ pada perusahaan manufaktur yang terdaftar dalam Bursa Efek Indonesia periode 2010-2012 berpengaruh secara positif. Hal ini dapat ditunjukkan oleh nilai $\beta>0,00$. Pengaruh ini menunjukkan bahwa semakin besar ukuran KAP yang ditunjuk oleh perusahaan untuk memberikan opini maka akan berdampak semakin kuatnya pengaruh antara manajemen laba riil yang diinteraksikan dengan arus kas operasi abnormal terhadap arus kas operasi satu tahun ke depan (CFOt+1).

Hasil uji $\mathrm{F}$ juga membuktikan bahwa nilai signifikansinya 0,000 lebih kecil dari 0,05 dan nilai Fhitung 13.274 lebih besar dari Ftabel yaitu 3.0253, sehingga menunjukkan bahwa model yang digunakan dalam penelitian ini memang layak untuk digunakan.

Dari hasil analisis table diatas diketahui nilai R-square sebesar 0,140 yang menunjukan bahwa variabel independen yang ditunjukkan oleh Real Earning Management yang diproyeksikan dengan arus kas operasi abnormal dapat menjelaskan perubahanan variabel dependen yaitu arus kas operasi perusahaan satu tahun ke depan sebesar 0,140 atau $14 \%$ dan sisanya $86 \%$ dipengaruhi oleh variabel lain.

\section{Kesimpulan dan Saran \\ A. Kesimpulan}

Penelitian ini menguji secara empiris pengaruh manajemen laba riil terhadap arus kas operasi satu tahun ke depan dengan kualitas audit sebagai variabel pemoderasi. Berdasarkan pembahasan dan pengujian diatas maka beberapa hal yang dapat disimpulkan dari hasil penelitian ini adalah:

1. Hasil dari pengujian Hal diterima dimana hal ini menunjukkan bahwa manajemen laba riil yang diproksikan dengan arus kas operasi abnormal memiliki pengaruh terhadap arus kas operasi operasi satu tahun ke depan.

2. Hasil dari pengujian Ha2 diterima hal ini menunjukkan bahwa kualitas audit yang diproksikan dengan besarnya KAP berpengaruh terhadap interaksi yang muncul antara manajemen laba riil dengan arus kas operasi satu tahun ke depan.

\section{B. Keterbatasan dan Saran Penelitian}

Keterbatasan dalam penelitian ini terletak pada jumlah perusahaan manufaktur yang memiliki data tersaji dalam satuan rupiah dan terdaftar di Bursa Efek Indonesia periode 2010-2012. Dari data yang ada, sebanyak 138 perusahaan dihilangkan dari sampel dikarenakan tidak tersaji dalam satuan rupiah. Oleh karena itu, jumlah data yang ada berkurang banyak sehingga mengurangi jumlah sampel. Berkaitan dengan hasil yang didokumentasikan dalam penelitian ini, terdapat peluang penelitian lanjutan. 
Penelitian yang akan datang dapat menambah sampel penelitian dengan cara memperpanjang periode pengamatan sampel untuk memperkuat hasil penelitian serta mengubah variabel pemoderasi dengan variabel lain yang lebih berpontensi kuat mempengaruhi pengaruh Real Earning Management terhadap arus kas operasi satu tahun ke depan.

\section{Daftar Pustaka}

Ardiati, AloysiaYanti. 2003. Pengaruh Manajemen Laba terhadap Return Saham dengan Kualitas Audit Sebagai Variabel Moderating. Simposium Nasional Akuntansi VI. Surabaya.

Atiqah, Miratul. 2012. Pengaruh Risiko Ligitasi Terhadap Manajemen Laba dengan Kualitas Audit sebagai Variabel Moderating. Semarang

Becker, C.L.M.L Defond, J.Jiambalvo, K.R Subramanyam. 1998. The Effect of Audit Quality On Earnings Management. Contemporary Accounting Research.

Chen, Han Wen, Jeff Zeyun Chen, Gerald J. Lobo dan Yanyang Wang. 2011. Effects on Audit Quality on Earnings Management and Cost of Equity Capital: Evidence from China. Contemporary Accounting Research, Vol. 28, No.3

Cohen, Daniel A., Aiyeshe Dey, dan Thomas Z. Lys. 2008. Real and Accrual Earnings Management in The Pre- and Post-Sarbanes Oxley Period. The Accounting Review.

Fitriyani, Dewi., Prasetyo, Eko., Mirdah, Andi.,dan Eka, Wirnie.2008. Pengaruh Manajemen Laba Terhadap Kinerja Perusahaan dengan Kualitas Audit sebagai Variabel Moderasi. Working Paper. Universitas Jambi

Gerayli, Muhdi Safari, Abolfazl Momeni Yaanosari, and Ali Reza Ma'atoofi. 2011. Impact of Audit Quality on Earnings Management (Evidence From Iran). International Research Journals of Finance and Economics, issue 66.

Ghozali, Imam. 2006. Analisis Multivariate dengan Program SPSS. Semarang: Badan Penerbit Universitas Diponegoro.

Graham, J.R., Harvey, C.R., dan Rajgopal, S. 2005. The Economic Implications of Corporate Financial Reporting. Journal of Accounting and Economics,40, p: 3-73.

Gunny, K. 2005. What are the Consequences of Real Earnings Management?". Working Paper. University of Colorado. 
Ikatan Akuntan Indonesia. (2012). Kerangka Dasar Penyusunan dan Penyajian Laporan Keuangan : Tujuan Penyajian Laporan Keuangan

Ikatan Akuntan Indonesia. (2012). Kerangka Dasar Penyusunan dan Penyajian Laporan Keuangan : Karakteristik Kualitatif Informasi Laporan Keuangan

Krishnan, G.V. 2003. Audit Quality and The Pricing of Discretionary Accruals. Journal of Practice and Theory, Vol. 22 No.1.

Parawiyati dan Zaki Baridwan. 1998. Kemampuan Laba dan Arus Kas dalam Memprediksi Laba dan Arus Kas Perusahaan Go Publik di Indonesia. Jurnal Riset Akuntansi Indonesia, Vol. 1, No. 1 (Januari): 1-11.

R. Scott, William.2003. Financial Accounting Theory Sixth Edition. Toronto, Ontario: Pearson Canada Inc.

Rezaei, F. 2012. Efficient or opportunistic earnings management with regards to the role of firm size and corporate governance practices. Interdisciplinary Journal of Contemporary Research Business January Vol. 3 No. 9 pp.1312-1322.

Roychowdhury, S. 2006. Earnings Management through Real Activities Manipulation. Journal of Accounting and Economics, 42, p: 335-370. Sloan School of Management.

Sahabu, Supardi. 2009. Manajemen Laba melalui Akrual dan Manipulasi Aktivitas Nyata dan Pengaruhnya Terhadap Kinerja Jangka Panjang Perusahaan Yang Melakukan Penawaran Right Issue. Tesis S2 Program Pasca Sarjana STIE YKPN, Yogyakarta.

Sanjaya. 2010. Entrenchment and Alignment Effect on Earnings Management. The Indonesian Journal of Accounting Research, 13(2): 247-264.

Scott, William R. (2000). Financial accounting Theory. Second edition. Canada: Prentice Hall

Scott, W.R. 2003. Financial Accounting Theory 3th Edition. Prentice Hall Inc. A Simon \&Schuter Company, Upper Saddle River. New Jersey, USA.Siregar, Slyvia., Veronica, N.P., dan Utama, Sidharta. 2006. Pengaruh Struktur Kepemilikan, Ukuran Perusahaan, dan Praktek Corporate Governance Terhadap Pengelolaan Laba (Earnings Management). Journal Riset Akuntansi Indonesia, Vol. 9 No. 3, hal. 307326. 
Subramanyam, K.R. 1996. The Pricing of Discretionary Accruals. Journal of Accounting and Economics 22 pp. 249-281.

Wedari, L.K. 2004. Analisis Pengaruh Dewan Komisaris dan Keberadaan Komite Audit Terhadap Aktivitas Manajemen Laba. Makalah Simposium Nasional Akuntansi VII. Denpasar, hal. 963-974.

Zang, A.Z. 2006. Evidence on the Trade-off Between Real Manipulation and Accrual Manipulation. Working Paper. Duke University. 